Saudi Journal of Medical and Pharmaceutical Sciences

Abbreviated Key Title: Saudi J Med Pharm Sci ISSN 2413-4929 (Print) |ISSN 2413-4910 (Online) Scholars Middle East Publishers, Dubai, United Arab Emirates Journal homepage: https://saudijournals.com/sjmps

Original Research Article

\title{
FTIR Based Pharmacological Validation of Bridelia retusa
}

\author{
Somendra Kumar, Dinesh Kumar, Motiram Sahu, Anil Kumar*
}

Department of Biotechnology, Govt. V.Y.T. PG. Autonomous College, Durg, Chhattisgarh, 491001, India

DOI: $10.36348 /$ sjmps.2020.v06i10.004

| Received: 09.10.2020 | Accepted: 24.10.2020 | Published: 29.10.2020

*Corresponding author: Anil Kumar

\section{Abstract}

Bridelia retusa commonly known as Khaja or Kasai in India, belonging to the family Euphorbiaceae, is a tropical smallsized tree found throughout warmer parts of India. Entire parts of Bridelia retusa has been traditionally used for healing of several ailments such as rheumatism, diabetes, diarrhea, dysentery, removal of urinary concretions, and the bark of the plant is used by tribal people to develop sterility as a contraceptive. The present investigation was planned to evaluate and explore potential bioactive phytocompounds in the bark, fruit, and leaf extract of Bridelia retusa using phytochemical profiling and an infra-red spectrophotometer. The phytochemical evaluation of bark, fruit, and leaf extracts of Bridelia retusa revealed the presence of alkaloids, cardiac glycosides, flavonoids, saponins, steroids, tannins, and terpenoids in extracts. All seven phytocompounds were found in both aqueous leaf and methanolic bark extracts. Alkaloid was detected in all except for ethyl acetate extract. Cardiac glycosides were found in extracts of aqueous and petroleum ether. Steroid and terpenoids were detected from all aqueous and methanol extracts whereas saponin was found in all aqueous extracts. FTIR spectrophotometric analysis exhibited the presence of primary \& secondary alcohols, alkenes, aldehyde, primary \& secondary amines, aliphatic bromo compounds, aliphatic ether, aromatic amines, acid halides, ester, halo compounds, vinyl ether, and aromatic compounds. The presence of these phytocompounds suggests better possibilities for the plant as a source of significant phytomedicines in pharmaceutical industries and research institutes for the discovery of lead compounds for a competent drug.

Keywords: Bridelia retusa, Phytocompounds, FTIR.

Copyright (C) 2020 The Author(s): This is an open-access article distributed under the terms of the Creative Commons Attribution 4.0 International License (CC BY-NC 4.0) which permits unrestricted use, distribution, and reproduction in any medium for non-commercial use provided the original author and source are credited.

\section{INTRODUCTION}

Natural products like herbal ingredients have evolved over a million years associated with the development of human civilization for a vital source of primary health needs. From the prehistoric era, medicinal plants have contributed a significant role in the human health care system. Phytocompounds of the medicinal plant are the chief source for the discovery of drugs or lead compounds because it holds a diversity of multi-dimensional chemical structures which show a wide variety of biological activities [1].

Naturally, derived products such as herbal ingredients are a vital source for medicinal preparations and pharmaceutical industries because of their unique diversified multidimensional chemical structures, noteworthy mechanisms of action, and their ability to interact with several biological targets [2]. At present demands for herbal products and medicinal plants is progressively growing in developing countries because of their availability to common individuals, efficiency, low side effects, quality, and remarkable pharmacological applications [3].

Herbal ingredients are popular and chief sources for medications worldwide from the prehistoric era. World Health Organization (WHO) reported that $80 \%$ of the global population almost depends on traditional herbal drugs or natural ingredients for primary health needs. Natural products from herbal plants continue to play the most important role in the discovery of lead compound and drug development processes. Hence it is an urgent need to study the various potential pharmacological aspects of medicinal plants [4].

The present research work has been designed to evaluate preliminary phytochemical profiling and FTIR spectrophotometric analysis of Bridelia retusa for exploring numerous bioactive phytocompounds found in bark, fruit, and leaf. Bridelia retusa commonly known as Spinous Kino Tree, Kasai, or Khaja, Asana is a moderate size deciduous tree, belonging to the family Euphorbiaceae, distributed worldwide and also in 
warmer parts of India. Whole plant parts are used in the traditional system of medicine for the treatment of different types of diseases such as rheumatism, diabetes, snake bites, fever, jaundice, liver diseases, wound healings, urinary tract infections, and sexual complications $[5,6]$.

More than 60 different species of Bridelia have been reported from Africa and Asia for their traditional applications like anti-inflammatory, hypoglycemic, anti-diarrhoeal, antinociceptive, antiviral, antimalarial, antibacterial, antiviral, anti anemic activities [7, 8]. The plant has been reported from Madagascar to Yemen, Sumatra, Indonesia, Myanmar, Nepal, Southern China, Bangladesh, Sri Lanka, Australia, and Tropical Africa. In India, it is most frequently found in Western Ghats of South Maharashtra and Western and Northern parts of India $[6,9]$.

Bridelia retusa is a moderate-sized 10 to 20 meter deciduous tree and the bark is rough, greyishbrown, internally blaze red. Leaves are simple, lateral, alternate; deciduous, stipules $7 \mathrm{~mm}$ long, petiole 9-15 $\mathrm{mm}$ long, margin entire or slightly crenulate, bright green. Flowers are unisexual, greenish-yellow, sessile or shortly pedicellate, organized in axillary fascicles. The fruit is 7-8 $\mathrm{mm}$ in size, green color in young which is changes to purplish-black in ripening $[10,6,11]$.
Systemics of Bridelia retusa:

\begin{tabular}{|l|l|}
\hline Kingdom & Plantae \\
\hline Division & Spermatophyta \\
\hline Class & Diocotyledonae \\
\hline Order & Malpighiales \\
\hline Family & Euphorbiaceae \\
\hline Genus & Bridelia \\
\hline Species & retusa \\
\hline
\end{tabular}

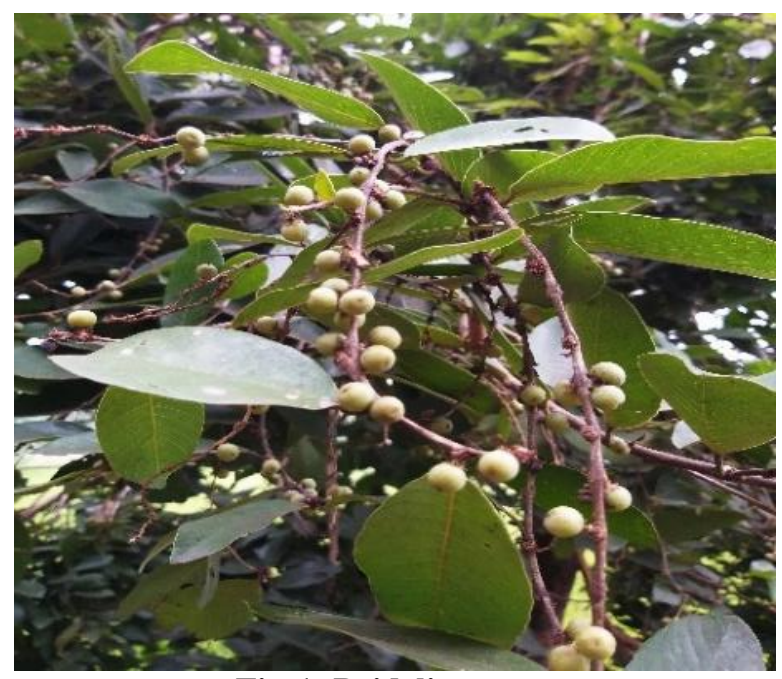

Fig-1: Bridelia retusa

The vernacular name of Bridelia retusa

\begin{tabular}{|l|l|}
\hline Sanskrit & Asan \\
\hline Hindi & Khaja, kaji, kassi, kuhir, kasai, kattian, ekdania \\
\hline Marathi & Asana \\
\hline Bengali & Geio \\
\hline Kannada & Asana, komanji, koyamarwa, nasinage, mulluhonne mara \\
\hline Malayalam & Malkani, mulluvenga \\
\hline Oriya & Asano \\
\hline Telugu & Kora made \\
\hline Tamil & Mullu-vengai, adamarudu, kaduga \\
\hline Assamese & Kuhir, kunhi, kuhit \\
\hline Others & Spino kino tree, gayo, garo khasi \\
\hline
\end{tabular}

\section{MATERIALS AND METHODS}

\section{Chemical reagents}

For the present study, analytical grade chemicals were used without further purification. All biochemicals were purchased from HI-MEDIA Pvt. Ltd., Mumbai.

\section{Collection of plant materials}

The plant was collected from the rural area of Durg district, Chhattisgarh, India during January 2020. Department of Botany, Govt. V.Y.T. PG. Autonomous College, Durg, Chhattisgarh, India, identified the harvested material. The plant samples leaf, bark, and fruit were rinsed thrice with distilled water followed by double distilled water to remove the dust and other contaminants then air-dried at $25-30^{\circ} \mathrm{C}$ for three weeks followed by the grinding process and the fine powder was kept in well-labeled air-tight containers and kept in dark at $-20^{\circ} \mathrm{C}$ till analysis.

\section{Plant Extract preparation}

The powdered plant materials from leaf, bark, and fruit (150 g each) were extracted successively with six solvents like- petroleum ether, benzene, chloroform, ethyl acetate, methanol, and distilled water (aqueous) using Soxhlet extractor at 55 to $85^{\circ} \mathrm{C}$ for 6 to 10 hours to extract the polar and non-polar compounds [12]. Each extract was filtered through Whatman filter paper (No.1) and then preserved in sterile air-tight bottles for further analysis.

\section{Qualitative phytochemical analysis}

Qualitative phytochemical analysis was carried out to detect the important phytocompounds like- 
alkaloid, cardiac glycosides, flavonoids, saponins, steroids, tannins, and terpenoids using the following standard protocols with some modifications.

\section{Test for Alkaloids}

$0.5 \mathrm{ml}$ extract, $3 \mathrm{ml}$ of methanol, $300 \mu \mathrm{l}$ of acetic acid were mixed and then few drops of ammonium hydroxide solution was added. Formation of precipitate showed the presence of alkaloids in the sample extract.

\section{Test for cardiac glycosides}

$0.5 \mathrm{ml}$ of extract, $0.2 \mathrm{ml}$ glacial acetic acid and dropwise $3.5 \%$ ferric chloride were added then layered with $1 \mathrm{ml}$ of conc. sulfuric acid. The formation of a reddish-brown ring at the interface indicated the presence of cardiac glycosides in the sample extract.

\section{Test for flavonoids}

$0.5 \mathrm{ml}$ plant extract, $5 \mathrm{ml}$ distilled water were mixed in the test tube then it was filtered. $5 \mathrm{ml}$ of dilute ammonium solution and then conc. sulfuric acid was added. The formation of yellow color indicated the presence of flavonoids in the sample extract.

\section{Test for saponin}

$2.5 \mathrm{ml}$ of extract, $5 \mathrm{ml}$ of distilled water were added and then solution was vigorously shaken and the formation of bubbles or stable persistence of foam indicated the presence of saponins in sample extract.

\section{Test for steroids}

$0.5 \mathrm{ml}$ of extract, $3 \mathrm{ml}$ of chloroform was added and then the solution was filtered then $2 \mathrm{ml}$ of conc. sulfuric acid was added to the filtrate. The formation of a reddish-brown ring at the interface indicated the presence of steroids in the sample extract.

\section{Test for tannins}

$0.5 \mathrm{ml}$ of extract, $5 \mathrm{ml}$ of distilled water were added than $1 \%$ ferric chloride was added. The appearance of deep green coloration indicated the presence of tannin in the sample extract.

\section{Test for Terpenoids}

$0.5 \mathrm{ml}$ extract, $2 \mathrm{ml}$ of chloroform were mixed then a few drops of concentrated sulfuric acid was added. The appearance of the reddish-brown color at the interface showed the presence of terpenoids in the sample extract.

\section{FTIR spectroscopic Analysis}

Fourier transforms infrared (FTIR) spectroscopy was used to determine the possible functional groups (types of chemical bonds) present in leaf, bark, and fruit extracts of Bridelia retusa based on the peak value in the region of infrared radiation. Infrared (IR) analysis was done with the aid of an infrared spectrophotometer (BRUKER, ALPHA II, ECO ATR) at the Department of Chemistry, Govt. V.Y.T. PG. Autonomous College, Durg, Chhattisgarh, India.

\section{RESULTS AND DISCUSSION Qualitative phytochemical analysis}

In the present study shade-dried powdered bark, fruit, and a leaf of Bridelia retusa were successfully extracted in petroleum ether, benzene, chloroform, ethyl acetate, methanol \& distilled water (aqueous) and screened for the qualitative presence of major phytochemical groups like alkaloids, cardiac glycosides, flavonoids, saponins, steroids, tannins and terpenoids according to the standard method. The results of the phytochemical study have been summarized in Table-1 and in Fig-2.

The phytochemical analysis made for the leaf, bark, and fruit extract of Bridelia retusa revealed the presence of alkaloids, cardiac glycosides, flavonoids, saponins, steroids, tannins, terpenoids in extracts. Several studies reported the presence of these phytochemicals to have many biological and therapeutic applications, so this species is expected to have many medicinal uses. These results are comparable to those obtained by Banerjee and Kulkarni [13], who studied preliminary phytochemical and pharmacognostic analysis of bark of Bridelia retusa Spreng. The study revealed that bark of Bridelia retusa possesses different phytoconstituents like alkaloids, flavonoids, glycosides, steroids, triterpenoids, tannins, and sugar. Similarly, Owk and Lagudu, in 2016 [14] used distilled water, methanol, chloroform, and hexane solvent system for extraction of fruit extract and investigated phytochemical constituents of Bridelia retusa (L.) Spreng. and their antimicrobial potency. The study revealed that the fruit extract of Bridelia retusa possesses numerous phytocompounds like alkaloids, anthraquinone, amino acids, cardiac glycosides, carbohydrates, glycosides, flavonoids, phenols, steroids, saponins, terpenoids, tannins, and volatile compounds. They also found that the methanol fruit extract of Bridelia retusa showed positive results for all tested phytochemicals. Tripathi et al., in 2019 [15] carried out a preliminary phytochemical investigation of the leaf extract of Bridelia retusa and suggested that the presence of alkaloids, glycosides, phytosterols, phenolic compounds, proteins, and carbohydrates exhibited remarkable antibacterial potency against gram-positive, gram-negative bacteria and fungus.

Our result indicates that bark, fruit, and leaf extracts of Bridelia retusa exhibited the presence of valuable phytocompounds useful for various pharmacological applications. This study correlates with a similar observation made by Banerjee and Kulkarni, 2009 [13], Owk and Lagudu, 2016 [14] and Tripathi et al., 2019 [15]. 
Previous research works in different species of Bridelia also supported our research findings. Luka et al., in 2020 [16] investigated the phytochemical study of aqueous and ethanolic extracts of stem and root-bark of Bridelia ferruginea Benth. and revealed the presence of various versatile phytocompounds such as alkaloids, anthraquinones, flavonoids, saponins, and tannins in root- bark extract whereas the stem-bark extract contains all the phytochemicals except anthraquinones. Ramesh et al., in 2001 [17] investigated preliminary phytochemical analysis of the bark of Bridelia crenulate and reported flavone and lignin present in chloroform and methanol extract, steroid and triterpene in chloroform, hexane and methanol extracts, saponin, quinone, phenol, tannin, protein, sugar, and starch in methanol extract while alkaloids and coumarins absence in all the extracts. Previously, Adebayo and Ishola in 2009 [18] studied phytochemical and antimicrobial analysis of a crude extract of leaves, root, and stem bark of Bridelia ferruginea and reported similar phytocompounds such as alkaloids, flavonoids, tannins, saponins, steroids additionally anthraquinones and phlorotannins. Vinatha et al., in 2017 [19] studied major phytoconstituents present in ethanolic extract of the leaves of Bridelia montana (ROXB) WILLD and reported phytochemical analysis of the ethanolic leaf extract exhibited the presence of different phytocompounds like alkaloids, glycosides, tannins, resins, and phenolic compounds.

\section{FTIR spectroscopic Analysis}

Fourier transform infrared spectrometry (FTIR) is a reliable, sensitive, and most powerful Physico-chemical analytical technique used to detect the possible functional groups or types of chemical bonds of bioactive components present in a plant or related resources based on the peak value in the region of infrared radiation. The FTIR tools perceive the vibrations of bonds in chemical functional groups and produce a spectrum that can be observed as a biochemical or metabolic pattern of the sample based on its peak's ratio. The wavelength of light absorbed is the features of the chemical bonds that can be perceived in the interpreted spectrum. The chemical bonds present in bioactive components can be measured by the interpretation of the absorbed infrared spectrum [2022].

In our study different solvent systems were used for the extraction of plant samples therefore different characteristic absorption peaks in their FTIR spectrum were observed but all pointed towards the same constituents present in the leaf, bark, and fruits extracts of Bridelia retusa. The slight differences in their spectrum were because of each solvent have specific ability to extract different bioactive constituents present in plant sample based on polarity.
The FTIR spectrum observed in leaf, bark and fruit extracts of Bridelia retusa in the ranges of 4000$3500 \mathrm{~cm}^{-1}, 3500-3300 \mathrm{~cm}^{-1}, 3000-2500 \mathrm{~cm}^{-1}$, 2400$2000 \mathrm{~cm}^{-1}, 1760-1690 \mathrm{~cm}^{-1}, 1680-1600 \mathrm{~cm}^{-1}, 1600$ $1300 \mathrm{~cm}^{-1}, 1470-1340 \mathrm{~cm}^{-1}, 1300-1050 \mathrm{~cm}^{-1}, 1250$ $1020 \mathrm{~cm}^{-1}, 950-675 \mathrm{~cm}^{-1}, 900-690 \mathrm{~cm}^{-1}$ and $700-600$ $\mathrm{cm}^{-1}[23,24,21]$.

Figures 03 to 11 represented the FTIR spectrum of bark, fruit, and leaf extracts of Bridelia retusa and possible functional groups present in plant extract are given in Table No. 02. By FTIR analysis, we found that the several functional group constituents of Bridelia retusa like primary \& secondary alcohols, alkenes, aldehyde, primary \& secondary amines, aliphatic bromo compounds, aliphatic ether, aromatic amines, acid halides, ester, halo compounds, vinyl ether and aromatic compounds which are major components of important secondary metabolites of the plant.

FTIR spectrum of aqueous bark extract has been depicted in Figure 03. The peaks at 3389.17, $1632.36,1048.79$, and $774.60 \mathrm{~cm}^{-1}$ correspond to the functional groups such as alcohols, phenols (O-H stretching), conjugated alkene $(\mathrm{C}=\mathrm{C}$ stretching $)$, primary amines (C-N stretching), and aromatic rings (C-H stretching) have been reported. Similarly, FTIR spectrum analysis of leaf aqueous extract of Abutilon indicum was analyzed in a previous study and reported the absorption bands at 3436.2, 1636.2, 1407.1, 1347.6, 1130.4 and $1047.1 \mathrm{~cm}^{-1}$ indicates the presence of functional groups such as phenols, amides, carboxylic acids, alkanes, secondary alcohols and sulfur compounds [50].

The infrared spectrum of aqueous fruit extract of Bridelia retusa has been presented in Figure 04. The characteristic absorption bands at 3379.68, 1639.30, 973.49 , and $777.25 \mathrm{~cm}^{-1}$ showed the presence of functional groups such as alcohols, phenols $(\mathrm{O}-\mathrm{H}$ stretching), alkane (C-H stretching), alkenes $(\mathrm{C}=\mathrm{C}$ stretching), and aromatic rings ( $\mathrm{C}-\mathrm{H}$ stretching) have been reported. Rajiv et al., in 2017 [26] investigated FTIR spectrophotometric analysis of an aqueous extract of Myristica dactyloids and reported the broad absorption peaks at 2723.49, 1651.07, 1527.62, $1404.18,1273.02,1126.43,933.55,833.25$ and 740.67 $\mathrm{cm}^{-1}$ indicated the presence of functional groups such as aldehydes ( $\mathrm{C}-\mathrm{H}$ stretching), alkenes ( $\mathrm{C}=\mathrm{C}$ stretching), nitro compounds (N-O stretching), aromatics (C-C stretching), alcohols, carboxylic acids, esters, ethers (C$\mathrm{O}$ stretching), carboxylic acids (O-H bending) and primary \& secondary amines (N-H stretching).

FTIR spectrophotometric spectrum of aqueous leaf extract of Bridelia retusa has been shown in Figure 05. The broad peaks at 3338.52, 3264.64, 2859.79, $2798.18,1635.98,1063.67$, and $989.27 \mathrm{~cm}^{-1}$ represent the presence of functional groups such as secondary 
amine (N-H stretching), alcohols (O-H stretching), alkane (C-H stretching), aldehyde (C-H stretching), conjugated alkene $(\mathrm{C}=\mathrm{C}$ stretching), primary alcohol (C-O stretching) and alkene $(\mathrm{C}=\mathrm{C}$ stretching) have been reported. Similar experiment was carried out from leaf extract of Andrographis paniculate and reported broad FTIR bands at $3749.62 \mathrm{~cm}^{-1}$ for phenol, $3402.43 \mathrm{~cm}^{-1}$ for amines, $2942.09 \mathrm{~cm}^{-1}$ for nitriles, $2854.65 \mathrm{~cm}^{-1}$ for alkanes, $2376.86 \mathrm{~cm}^{-1}$ for alkynes, $1635.64 \mathrm{~cm}^{-1}$ for alkenes, $1327.03 \mathrm{~cm}^{-1}$ for alcohols, carboxylic acids, esters and ethers, $1072.42 \mathrm{~cm}^{-1}$ for aliphatic amines $1033.85 \mathrm{~cm}^{-1}$ for alkenes and $894.97 \mathrm{~cm}^{-1}$ for aromatic amines [27].

The wide-ranging infrared spectrum of methanol bark extract of Bridelia retusa has been presenred in Figure 06. Representative absorption bands were exhibited at $3319.03 \mathrm{~cm}^{-1}$ for secondary amine $(\mathrm{N}$ $\mathrm{H}$ stretching), 2943.58, 2831.65, 1449.08, $1413.97 \mathrm{~cm}^{-1}$ for alkane (C-H stretching), $1115.03 \mathrm{~cm}^{-1}$ for secondary alcohol (C-O stretching), $1027.28 \mathrm{~cm}^{-1}$ for aromatic amines (C-N stretching) and $652.53 \mathrm{~cm}^{-1}$ for halo compound (C-Br stretching). Similarly, FTIR spectral analysis of Clitoria ternatea leaves extract was carried out and reported that the presence of functional groups such as alkanes, aromatic amines, phenols, primary and secondary amines was responsible for the different therapeutic applications [28].

Infrared spectrophotometric peaks of methanol fruit extract of Bridelia retusa has been shown in Figure 07. The characteristic absorption bands were exhibited at $3320.50 \mathrm{~cm}^{-1}$ for secondary amine (N-H stretching), 2943.75, 2831.70, 1449.19, $1414.90 \mathrm{~cm}^{-1}$ for alkanes (C-H bending), $1115.26 \mathrm{~cm}^{-1}$ for secondary alcohol (CO stretching), $1024.12 \mathrm{~cm}^{-1}$ for aromatic amines (C-N stretching) and $656.17 \mathrm{~cm}^{-1}$ for halo compound (C-Br stretching). Similar results were reported from methanolic fruit extract of Myristica dactyloides and observed the bands at 2831.50, 1442.75, 1111.00 and $1026.13 \mathrm{~cm}^{-1}$ which correspond to functional groups such as alcohols, phenols (O-H stretching), carboxylic acids (O-H stretching), aromatics (C-C stretching, aliphatic amines (C-N stretching) and alcohols, carboxylic acids, esters, ethers (C-O stretching) [26].

FTIR spectrum of methanol leaf extract of Bridelia retusa showed wide-ranging characteristic absorption spectra at $3320.97 \mathrm{~cm}^{-1}$ for secondary amine (N-H stretching), 2985.39, 2944.41, 2831.84, 1449.08, $1405.51 \mathrm{~cm}^{-1}$ for alkanes (C-H bending), $1216.75 \mathrm{~cm}^{-1}$ for vinyl ether (C-O stretching), $1106.67 \mathrm{~cm}^{-1}$ for aliphatic ether (C-O stretching), $1020.95 \mathrm{~cm}^{-1}$ for aromatic amines (C-N stretching), $758.43 \mathrm{~cm}^{-1}$ for aromatic rings (C-H bend), $718.80 \mathrm{~cm}^{-1}$ for alkene ( $\mathrm{C}=\mathrm{C}$ bending), $662.43 \mathrm{~cm}^{-1}$ for halo compound $(\mathrm{C}-\mathrm{Br}$ stretching) (Figure-8). The observed spectrophotometric bands were ranged from strong, medium, sharp, and weak absorption spectrum. Similar research was carried out in methanolic leaves extract of Embelia ribes and observed bands at 3344.93, 2936.09, 2832.92, 1644.98, 1455.99, 1021.12, 799.35, 635.43, and $624.323 \mathrm{~cm}^{-1}$ indicates the presence of numerous functional group such as alcohol, amines, amides, alkanes, carboxylic acid, aromatic, aliphatic amines, alcohols, aromatic compound, aldehyde, halogen, alkyl halide, alkynes, and disulfides [24]. Sunil et al., 2018 [22] investigated FTIR spectrophotometric analysis of methanolic leaf extract of Coriandrum sativum and observed FTIR spectrum at $3372.30,2925.88,2854.49,1741.42$, $1639.41,1411.62,1253.54,1157.17,1099.87,1061.20$ and $623.75 \mathrm{~cm}^{-1}$ refers to the presence of functional groups such as amines ( $\mathrm{N}-\mathrm{H}$ stretching), alkyl $(\mathrm{C}-\mathrm{H}$ stretching), alkane (C-H stretching), ester $(\mathrm{C}=\mathrm{O}$ stretching), alkene $(\mathrm{C}=\mathrm{C}$ stretching $)$, aromatic $(\mathrm{C}=\mathrm{C}$ stretching), acid (C-O stretching), amine (C-N stretching), secondary alcohol (C-O stretching), primary alcohol (C-O stretching) and alkyl halide (C-CL stretching).

The infrared spectrophotometric spectrum of ethyl acetate fruit extract of Bridelia retusa has been presented in Figure-9. The characteristic absorption bands were exhibited at 2984.31, 2917.45, $2849.96 \mathrm{~cm}^{-1}$ for functional group alkane (C-H stretching), 1737.49 $\mathrm{cm}^{-1}$ for aldehyde ( $\mathrm{C}=\mathrm{O}$ stretching), $1372.63 \mathrm{~cm}^{-1}$ for alkanes (C-H bending), and 1236.24, 1233.94, 1043.54 $\mathrm{cm}^{-1}$ for amine (C-N stretching). Similar research work was carried out by Rajiv et al., 2017 [26] in ethyl acetate fruit extract of Myristica dactyloids and observed the bands at 2985.81, 1743.65, 1442.75, 1242.16, 1049.28, 933.55, 848.68, 786.96 and 702.09 $\mathrm{cm}^{-1}$ represent the presence of functional groups such as alkenes ( $\mathrm{C}-\mathrm{H}$ stretching), carboxylic acids $(\mathrm{C}=\mathrm{O}$ stretching), aromatics (C-C stretching), alcohols, carboxylic acids, esters, ethers (C-O stretching), aliphatic amines (C-N stretching), carboxylic acids (O$\mathrm{H}$ bend) and primary and secondary amines (N-H stretching) were responsible for potential medicinal uses.

FTIR spectrophotometric spectrum of chloroform fruit extract of Bridelia retusa showed characteristic absorption bands at 2918.70, $2850.40 \mathrm{~cm}^{-}$ ${ }^{1}$ for alkane (C-H stretching), $1738.11 \mathrm{~cm}^{-1}$ for aldehyde (C-H stretching), $1462.73 \mathrm{~cm}^{-1}$ for alkane (C-H bending), $1214.53 \mathrm{~cm}^{-1}$ for amine (C-N stretching) and $767.66 \mathrm{~cm}^{-1}$ for aromatic compound (C-H bend) (Figure-10). Previously similar research work was investigated for chloroform leaf extract of Phyllanthus amarus \& Senna auriculata and FTIR bands were reported at $2927 \& 2912 \mathrm{~cm}^{-1}$ for C-H stretching, 1492 $\mathrm{cm}^{-1}$ for $\mathrm{C}-\mathrm{H}$ stretching, 1710 and $1718 \mathrm{~cm}^{-1}$ for carbonyl groups [29]. Deshmukh in 2017 [30] studied similar research in chloroform extract of Cyclea peltata (Lamk.) and observed FTIR bands at $3679.64 \mathrm{~cm}^{-1}$ for $\mathrm{O}-\mathrm{H}$ stretching, $3022.82 \mathrm{~cm}^{-1}$ for $\mathrm{C}-\mathrm{H}$ stretching, $2353.94 \mathrm{~cm}^{-1}$ for $\mathrm{C}=\mathrm{N}$ stretching, $1714.63 \mathrm{~cm}^{-1}$ for $\mathrm{C}=\mathrm{O}$ 
stretching, $1525.03 \mathrm{~cm}^{-1}$ for $\mathrm{C}=\mathrm{C}$ stretching and $1425.96 \mathrm{~cm}^{-1}$ bendings.

The infrared spectrophotometric spectrum of benzene fruit extract of Bridelia retusa has been presented in Figure-11. The characteristic absorption band was exhibited at $3090.77,3071.24,3035.52 \mathrm{~cm}^{-1}$ for alcohol, phenol (O-H stretching), $1789.06 \mathrm{~cm}^{-1}$ for acid halide $\left(\mathrm{C}=\mathrm{O}\right.$ stretching), $1477.78 \mathrm{~cm}^{-1}$ for aromatic compounds $\left(\mathrm{C}=\mathrm{C}\right.$ stretch), $1034.85 \mathrm{~cm}^{-1}$ for aromatic amines (C-N stretching) and $660.02 \mathrm{~cm}^{-1}$ for aliphatic bromo compound (C-Br stretching). FTIR spectrophotometric analysis of Gliricidia sepium extract was investigated by Oladunmoye et al., [21] in earlier research work and found FTIR bands at 3354.32, $1735.99,1464.02,1049.31$ and $669.32 \mathrm{~cm}-1$ indicates the presence of functional groups such as alcohol/phenol (O-H stretching), carbonyl (C-H stretching), alkanes (C-H bending), aromatic amines (C-N stretching), aliphatic bromo compound (C-Br stretching).

Table-1: Qualitative phytochemical analysis of leaf, bark, and fruit extract of Bridelia retusa

\begin{tabular}{|c|c|c|c|c|c|c|c|c|c|c|c|c|c|c|c|c|c|c|}
\hline \multirow{3}{*}{$\begin{array}{l}\text { Bioactive } \\
\text { components }\end{array}$} & \multicolumn{18}{|c|}{ Nature of Plant Extract } \\
\hline & \multicolumn{3}{|c|}{$\begin{array}{l}\text { Distilled } \\
\text { water }\end{array}$} & \multicolumn{3}{|c|}{ Methanol } & \multicolumn{3}{|c|}{$\begin{array}{l}\text { Ethyl } \\
\text { acetate }\end{array}$} & \multicolumn{3}{|c|}{ Chloroform } & \multicolumn{3}{|c|}{ Benzene } & \multicolumn{3}{|c|}{$\begin{array}{c}\text { Petroleum } \\
\text { ether }\end{array}$} \\
\hline & $\mathrm{L}$ & B & $\mathrm{F}$ & $\mathrm{L}$ & B & $\mathrm{F}$ & $\mathrm{L}$ & B & $\mathrm{F}$ & $\mathrm{L}$ & B & $\mathrm{F}$ & $\mathrm{L}$ & B & $\mathrm{F}$ & $\mathrm{L}$ & $\mathrm{B}$ & $\mathrm{F}$ \\
\hline Alkaloids & + & + & + & + & + & + & + & - & + & + & + & + & + & + & + & + & + & + \\
\hline $\begin{array}{l}\text { Cardiac } \\
\text { Glycosides }\end{array}$ & + & + & + & - & + & + & - & + & + & - & + & + & - & + & + & + & + & + \\
\hline Flavonoids & + & - & - & + & + & + & + & - & + & - & - & - & + & - & + & - & - & - \\
\hline Saponins & + & + & + & + & + & - & - & - & - & - & - & + & - & + & + & - & - & - \\
\hline Steroids & + & + & + & + & + & + & - & - & + & - & + & + & - & + & + & - & + & + \\
\hline Tannins & + & - & - & + & + & + & + & - & - & - & - & - & + & - & - & - & - & - \\
\hline Terpenoids & + & + & + & + & + & + & - & - & + & - & + & + & - & + & + & - & + & + \\
\hline $\mathbf{L}=$ Leaf; $\mathbf{B}=$ & & & & & & & & & & & & $=\mathbf{P c}$ & & es & $-=$ & $\mathrm{Ne}$ & & \\
\hline
\end{tabular}
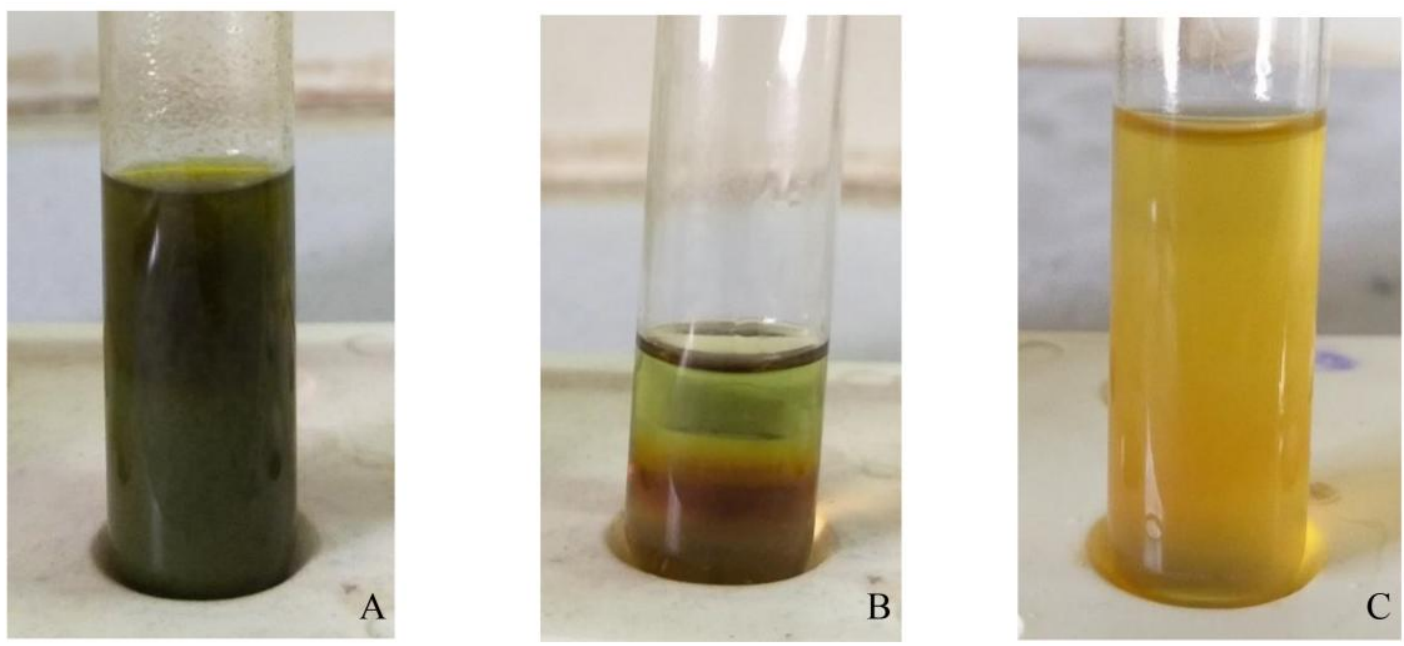

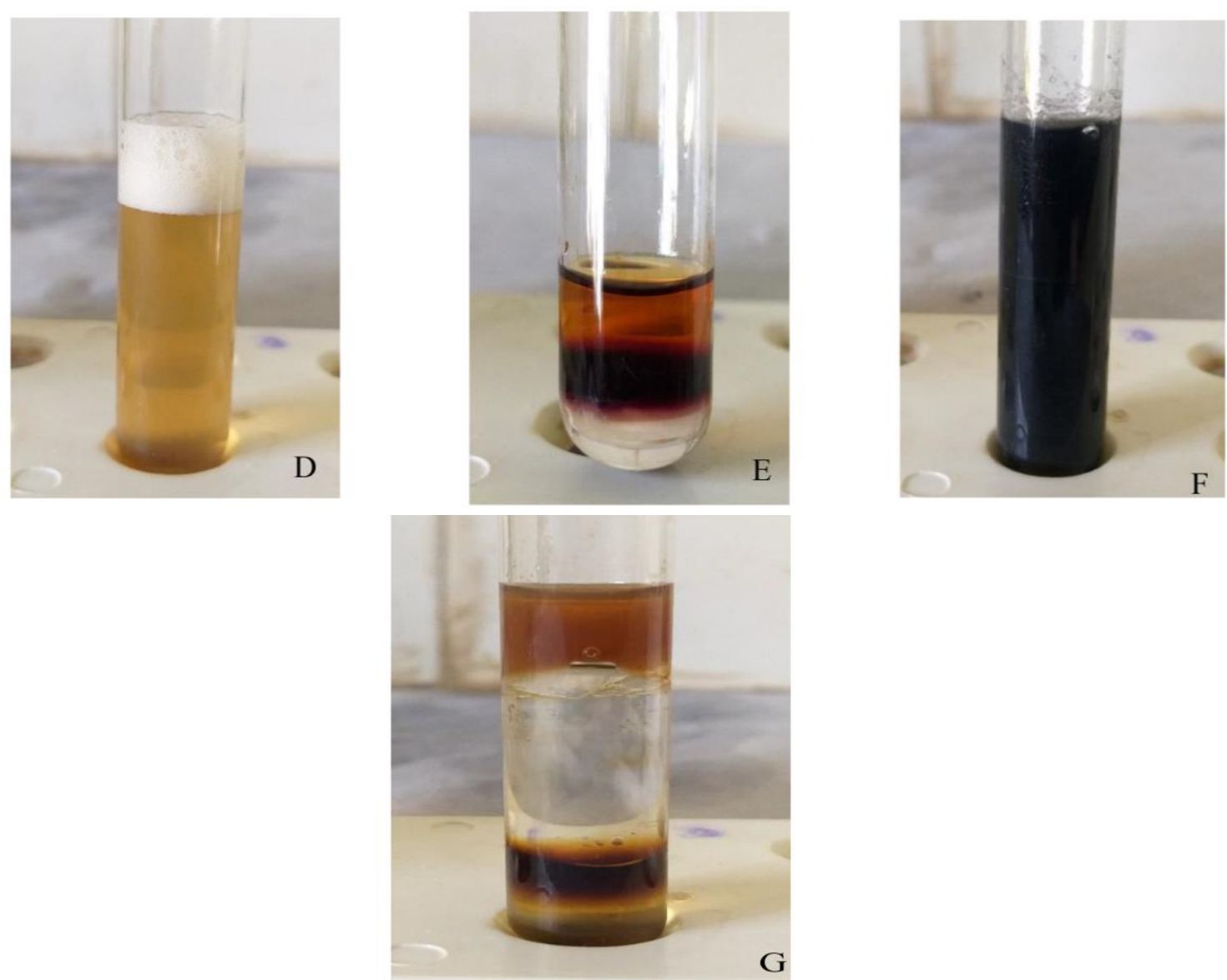

G

Fig-2: Showing qualitative phytochemical analysis of plant extract of Bridelia retusa

A- Alkaloid (appearance of precipitation); BCardiac glycosides (reddish-brown ring at the interface); C- Flavonoids (yellow color of solution); DSaponins (stable persistence of foam); E- Steroids (reddish-brown ring at interphase); F- Tannins (deep green solution); G- Terpenoids (reddish-brown color at interphase).

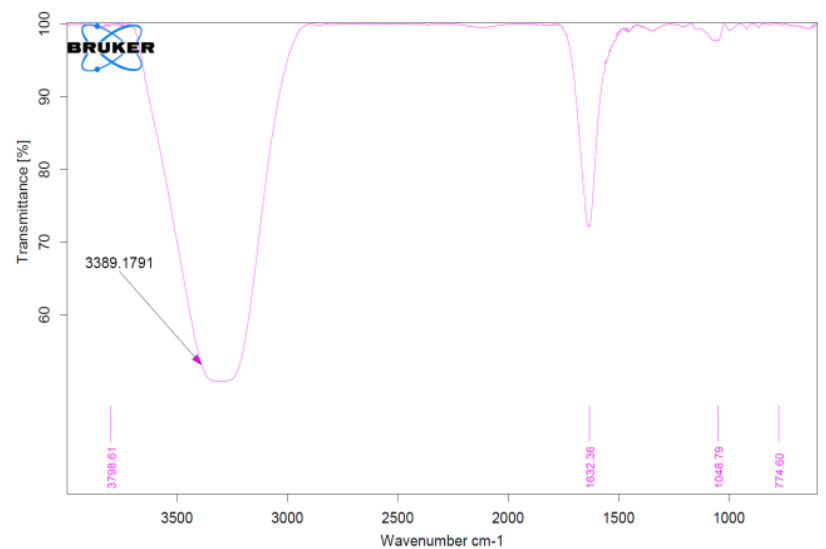

Fig-3: FTIR spectrum of aqueous bark extract of Bridelia retusa

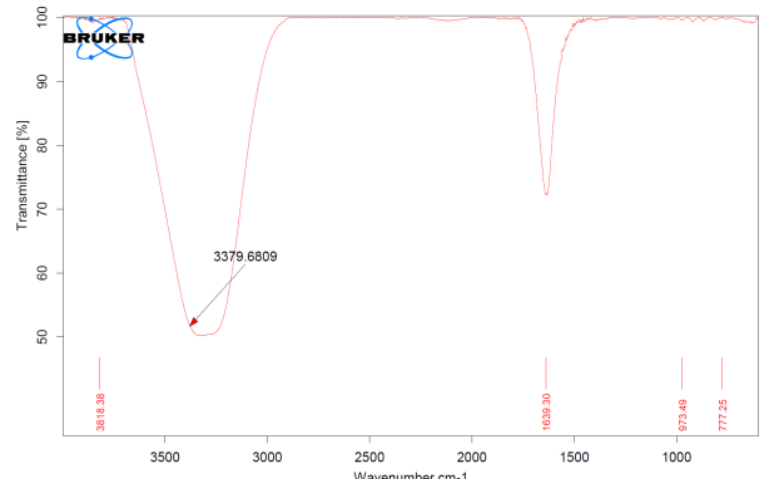

Fig-4: FTIR spectrum of aqueous fruit extract of Bridelia retusa

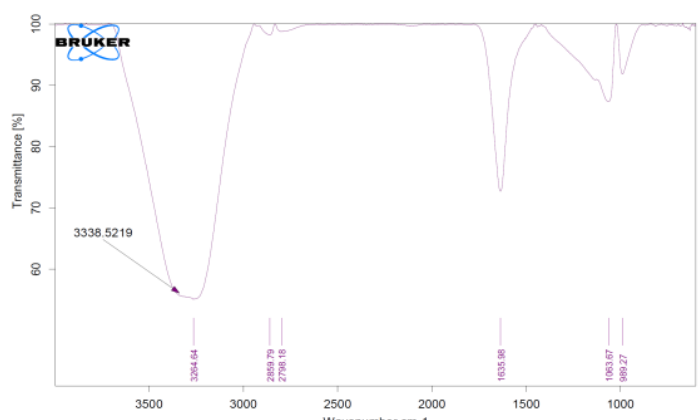

Fig-5: FTIR spectrum of aqueous leaf extract of Bridelia retusa 


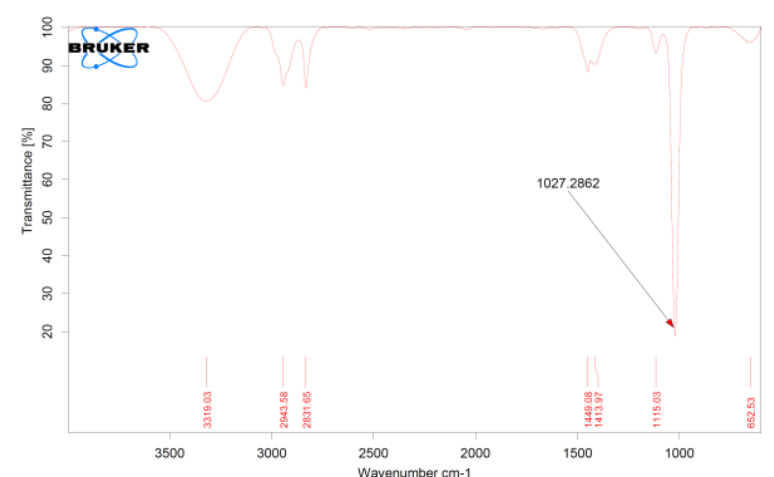

Fig-6: FTIR spectrum of methanol bark extract of Bridelia retusa

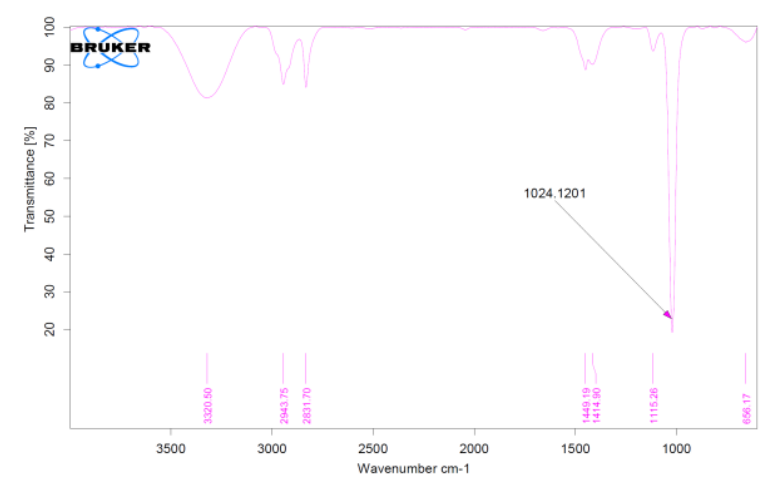

Fig-7: FTIR spectrum of methanol fruit extract of Bridelia retusa

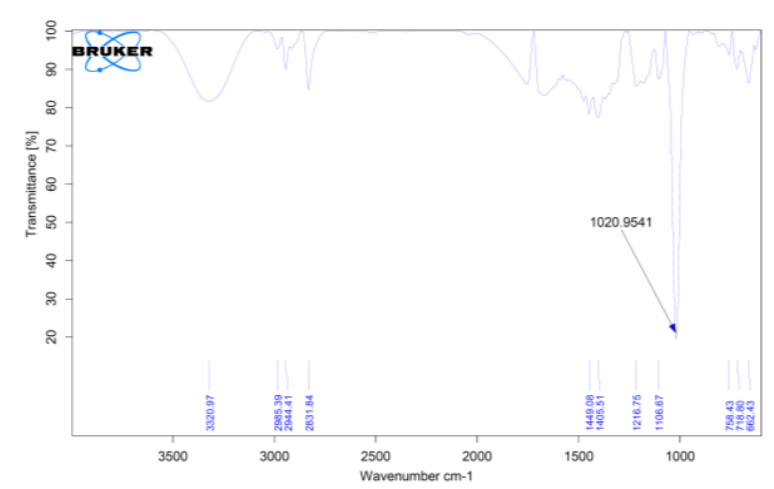

Fig-8: FTIR spectrum of methanol leaf extract of Bridelia retusa

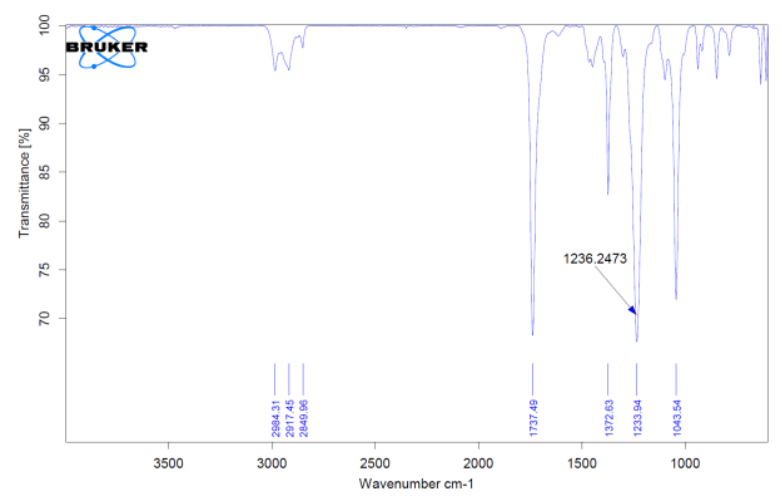

Fig-9: FTIR spectrum of ethyl acetate fruit extract of Bridelia retusa

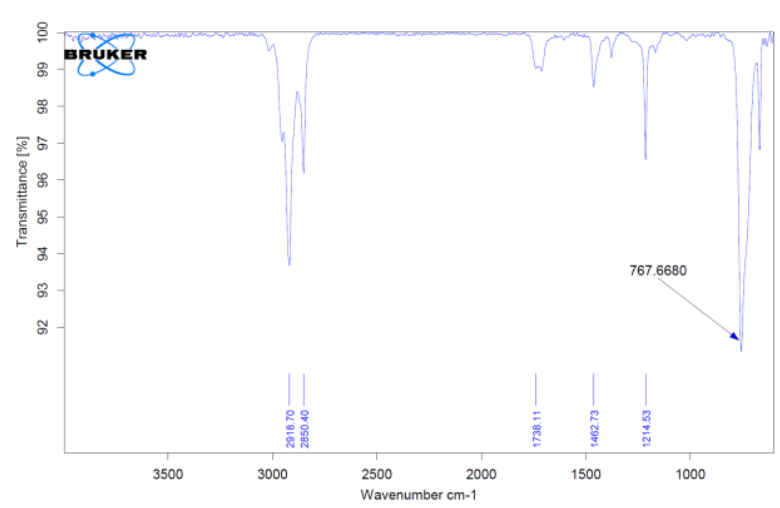

Fig-10: FTIR spectrum of chloroform fruit extract of Bridelia retusa

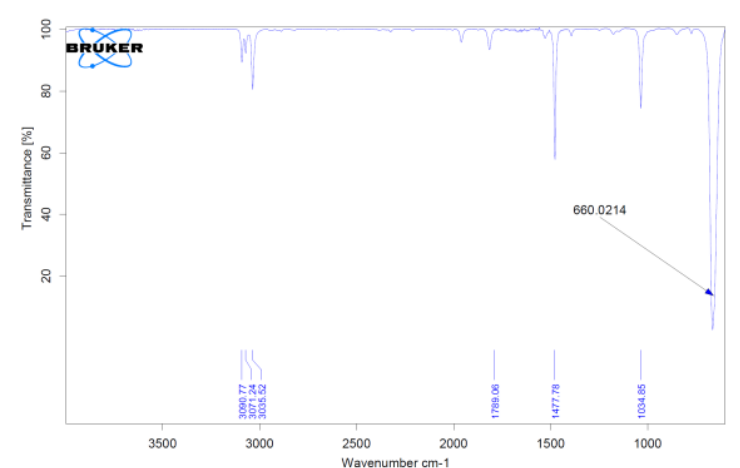

Fig-11: FTIR spectrum of benzene fruit extract of Bridelia retusa 
Somendra Kumar et al., Saudi J Med Pharm Sci, Oct, 2020; 6(10): 658-667

Table-2: Wavenumber $\left(\mathrm{cm}^{-1}\right)$ of dominant peak obtained from absorption spectra of plant extract of Bridelia retusa

\begin{tabular}{|c|c|c|c|c|c|c|c|c|c|}
\hline \multirow{2}{*}{$\begin{array}{l}\text { Possible } \\
\text { functional } \\
\text { groups } \\
\text { (Bond type) }\end{array}$} & \multicolumn{9}{|c|}{ Absorption Spectra $\left(\mathrm{cm}^{-1}\right)$} \\
\hline & $\begin{array}{l}\text { Aqueous } \\
\text { bark } \\
\text { extract }\end{array}$ & $\begin{array}{l}\text { Aqueous } \\
\text { fruit } \\
\text { extract }\end{array}$ & $\begin{array}{l}\text { Aqueous } \\
\text { leaf } \\
\text { extract }\end{array}$ & $\begin{array}{l}\text { Methanol } \\
\text { bark } \\
\text { extract }\end{array}$ & $\begin{array}{l}\text { Methanol } \\
\text { fruit } \\
\text { extract }\end{array}$ & $\begin{array}{l}\text { Methanol } \\
\text { leaf extract }\end{array}$ & $\begin{array}{l}\text { Ethyl } \\
\text { acetate } \\
\text { fruit } \\
\text { extract }\end{array}$ & $\begin{array}{l}\text { Chloroform } \\
\text { fruit } \\
\text { extract }\end{array}$ & $\begin{array}{l}\text { Benzene } \\
\text { fruit } \\
\text { extract }\end{array}$ \\
\hline $\begin{array}{l}\text { Alcohol, } \\
\text { phenols } \\
\text { (O-H } \\
\text { stretching) }\end{array}$ & 3389.17 & 3379.68 & $\begin{array}{l}3264.64 \\
1063.67\end{array}$ & 1115.03 & 1115.26 & - & - & - & $\begin{array}{l}3090.77 \\
3071.24 \\
3035.52\end{array}$ \\
\hline $\begin{array}{l}\text { Alkanes } \\
(\mathrm{C}=\mathrm{C} \\
\text { stretching) }\end{array}$ & 1632.36 & $\begin{array}{l}1639.30 \\
973.49\end{array}$ & $\begin{array}{l}2859.79 \\
1635.98 \\
989.27\end{array}$ & $\begin{array}{l}2943.58 \\
2831.65 \\
1449.08 \\
1413.97\end{array}$ & $\begin{array}{l}2943.75 \\
2831.70 \\
1449.19 \\
1414.90\end{array}$ & $\begin{array}{l}2985.39 \\
2944.41 \\
2831.84 \\
1449.08 \\
1405.51 \\
718.80\end{array}$ & $\begin{array}{l}2984.31 \\
2917.45 \\
2849.96 \\
1372.63\end{array}$ & $\begin{array}{l}2918.70 \\
2850.40 \\
1462.73\end{array}$ & - \\
\hline $\begin{array}{l}\text { Amines } \\
\text { (N-H } \\
\text { stretching) }\end{array}$ & 1048.79 & - & 3338.52 & $\begin{array}{l}3319.03 \\
1027.28\end{array}$ & $\begin{array}{l}3320.50 \\
1024.12\end{array}$ & $\begin{array}{l}3320.97 \\
1020.95\end{array}$ & $\begin{array}{l}1236.24 \\
1233.94 \\
1043.54\end{array}$ & 1214.53 & 1034.85 \\
\hline $\begin{array}{l}\text { Aldehyde } \\
\text { (C-H } \\
\text { stretching) }\end{array}$ & - & - & 2798.18 & - & - & - & 1737.49 & 1738.11 & - \\
\hline $\begin{array}{l}\text { Halo } \\
\text { compounds } \\
\text { (C-Br) }\end{array}$ & - & - & - & 652.53 & 656.17 & 662.43 & - & - & 660.02 \\
\hline $\begin{array}{l}\text { Aromatic } \\
\text { ring, } \\
\text { compounds } \\
\text { (C-H bend) }\end{array}$ & 774.60 & 777.25 & - & - & - & 758.43 & - & 767.66 & $\begin{array}{l}1789.06 \\
1477.78\end{array}$ \\
\hline $\begin{array}{l}\text { Ether (C-O } \\
\text { stretching) }\end{array}$ & - & - & - & - & - & $\begin{array}{l}1216.75 \\
1106.67\end{array}$ & - & - & - \\
\hline
\end{tabular}

\section{CONCLUSION}

Phytochemical investigation of Bridelia retusa revealed the presence of pharmacologically important several versatile phytoconstituents such as alkaloids, cardiac glycosides, flavonoids, saponins, steroids, tannins, and terpenoids. FTIR analysis of plant extracts showed many mediam, strong, sharp, and weak absorption bands which confirm many significant functional groups in the bark, fruit, and leaf extracts of Bridelia retusa. Interpretation of FTIR spectrum of bark, fruit, and leaf extracts suggested that the major functional groups constituent of Bridelia retusa are alcohols, aldehyde, alkenes, aliphatic bromo compounds, aromatic amines, aliphatic ether, acid halides, ester, halo compounds, primary \& secondary amines, vinyl ether and aromatic compounds which are major components of significant secondary metabolites of Bridelia retusa. Finally, it may be concluded that the outcomes of the present study support the traditional herbal application of the Bridelia retusa as a medicine. Hence, it is required to explore the wider benefit of the plant in the field of pharmaceutical sciences for further application. Further studies are essential about the suitable characterization, pharmackodynamic and pharmacokinetic study to establish lead compound for pharmacological applications.

\section{ACKNOWLEDGEMENT}

The authors are thankful to CSIR, New Delhi, for the award of Junior Research Fellowship.

\section{REFERENCES}

1. Mohanraj, K., Karthikeyan, B. S., Vivek-Ananth, R. P., Bharath Chand, R. P., Aparna, S. R., Mangalapandi, P., \& Samal, A. (2018). IMPPAT: A curated database of Indian Medicinal Plants, Phytochemistry, And Therapeutics. Scientific Reports, 8:4329.

2. Winter, J. M., \& Tang, Y. (2012). Synthetic biological approaches to natural product biosynthesis. Curr Opin Biotechnol, 23:736-743.

3. Vikram, P., Chiruvella, K. K., Abdullah Ripain, I. H. B., \& Arifullah, M. (2014). A recent review on phytochemical constituents and medicinal properties of kesum (Polygonum minus Linn.). Asian Pacific Journal of Tropical Biomedicine, 4(1):930-935.

4. Fabricant, D. S., \& Farnsworth, N. R. (2001). The value of plants used in traditional medicine for drug discovery. Environ Health Perspective, 109:69-75.

5. Tatiya, A. U., Tapadiya, G. G., Kotecha, S., \& Surana, S. J. (2011). Effect of solvents on total phenolics, antioxidant, and antimicrobial properties of Bridelia retusa Spreng. stem bark. Indian Journal of Natural Products and Resources, 2(4): 442-447.

6. Ghawate, V. B., Jadhav, V. S., \& Bhambar, R. S. (2015): Pharmacological Activities of Bridelia retusa: A Review. Journal of Pharmacy Research, 9(7):415-418.

7. Ngueyema, T. A., Brusotti, G., Caccialanzaa, G., \& Finzi, P. V. (2009). The genus Bridelia: A 
phytochemical and ethnopharmacological review. Journal of Ethnopharmacology, 124: 339-349.

8. Rupali, B. D., Narayan, N. P., \& Yuvraj, D. A. (2016). An overview of Bridelia Retusa Linn. World Journal of Pharmaceutical Sciences, 4(2):199-203.

9. Jayawikrama, W. G. M. M., Attanayake, A.R., Yapa, Y. A. A. B., Ratnasooriya, W. D., \& Pathirana, R. N. (2018). In vitro evaluation of anti rheumatoid arthritic and anti-inflammatory activities of aqueous bark extract of Bridelia retusa. Journal of Pharmacognosy and Phytochemistry, 7(3):3234-3236.

10. Kirtikar, K. R., \& Basu, B. D. (1999). Indian Medicinal Plants; International Book Distributors, Deharadun, India, 68-69.

11. India Biodiversity Portal. (2020): https://indiabiodiversity.org/species/show/264257

12. Elgorashi, E. E., \& Staden, V. J. (2004). Pharmacological screening of six Amaryllidaceae species. J Ethnopharmacol, 90:27-32.

13. Banerjee, S. K., \& Kulkarni, K. S. (2009). Pharmacognostic and preliminary phytochemical investigation on the bark of Bridelia retusa Spreng. International Journal of Pharmaceutical and Clinical Research, 1(1):35-39.

14. Owk, A. K., \& Lagudu, M. N. (2016). Bridelia retusa Spreng. Fruits: Antimicrobial Efficiency and their Phytochemical Constituents. Not Sci Biol, 8(1): 33-36.

15. Tripathi, R., Tiwari, A., \& Tiwari., A. (2019). Antimicrobial Activity of Bridelia retusa Against Human Pathogenic Microorganisms. International Journal of Advanced Scientific Research and Management, Special Issue 5, ISSN 2455-6378.

16. Luka, M. I., Onuoha, S. C., Oladele, V. O., \& Aguiyi, J. (2020). Phytochemical screening and in vitro evaluation of the antibacterial activity of aqueous and ethanolic extracts of root and stem bark of Bridelia ferruginea. Benth. (Euphorbiaceae). Journal of Medicinal Plants Research, 14(1):54-61.

17. Ramesh, N., Viswanathan, M. B., Saraswathy, A., Balakrishna, K., Brindha, P., \& Lakshmanaperumalsamy, P. (2001). Phytochemical and Antimicrobial Studies of Bridelia crenulate. Pharmaceutical Biology, 39(6): 460-464.

18. Adebayo, E. A., \& Ishola, O. R. (2009). Phytochemical and antimicrobial screening of the crude extracts from the root, stem bark, and leaves of Bridelia ferruginea. African Journal of Biotechnology, 8(4):650-653.

19. Vinatha, B., Kute, V., Kuchana, V., Shreelekha, J., Sreeharshini, K., \& Reddy, I. A. (2017). Phytochemical Screening, HPTLC Fingerprint Analysis of Leaf Extract of Bridelia montana (Roxb) Willd. International Journal of
Pharmacognosy and Phytochemical Research, 9(6):797-800.

20. Johnson, M., Bobby, N. M. D., \& Wesely, E. G. (2012). FTIR studies on the leaves of Albizia lebbeck benth. Int $\mathbf{J}$ of Pharm and Pharm Sci, 4(3):293-296.

21. Oladunmoye, M. K., Ayantola, K. J., Agboola, A. A., Olowe, B. M., \& Adefemi, O. G. (2018). Antibacterial and FTIR Spectral Analysis of Methanolic Extract of Gliricidia sepium Leaves. Journal of Advances in Microbiology, 9(4):1-10.

22. Sunil, K. S., Suma, A., Ashika, B. D., Roy, C. L., Naresh S., \& Sathyamurthy, B. (2018). GCMS And FTIR Analysis on the Methanolic Extract of Coriandrum Sativum Leaves. European Journal of Pharmaceutical and Medical Research, 5(8):454 460.

23. Sahayaraj, P. A., Gowri, J., Dharmalingama, V., Shobanaa, R., \& Prema, A. A. (2015). Phytochemical screening by FTIR spectroscopic analysis of leaf and stem Extracts of Wedelia biflora. Int J Nano Corr Sci and Engg, 2(5):322334.

24. Kamble, V., \& Gaikwad, N. (2016). Fourier Transform Infrared Spectroscopy Spectroscopic Studies in Embelia ribes Burm. F.: A Vulnerable Medicinal Plant. Asian J Pharm Clin Res, 9(3): 41-47.

25. Singh, R., \& Mendhulkar, V. D. (2015). FTIR studies and spectrophotometric analysis of natural antioxidants, polyphenols, and flavonoids in Abutilon Indicum (Linn) Sweet leaf extract. Journal of Chemical and Pharmaceutical Research, 7(6): 205-211.

26. Rajiv, P., Deepa, A., Vanathi, P., \& Vidhya, D. (2017). Screening for Phytochemicals and FTIR Analysis of Myristica dactyloids Fruit Extracts. Int J Pharm Pharm Sci, 9(1):315-318.

27. Sithara, N. V., Komathi, S., \& Rajalakshmi, G. (2017). Identification of bioactive compounds using different solvents through FTIR studies and GCMS analysis. Journal of Medicinal Plants Studies, 5(2):192-194.

28. Lakshmi, N. D. M., Mahitha, B., \& Madhavi, T. (2015). Phytochemical screening and FTIR analysis of Clitoria ternatea leaves. International Journal of Scientific \& Engineering Research, 6(2), 287-290.

29. Ashokkumar, R., \& Ramaswamy, M. (2014). Phytochemical screening by FTIR spectroscopic analysis of leaf extracts of selected Indian Medicinal plants. Int $\mathbf{J}$ Curr Microbiol App Sci, 3(1): 395-406.

30. Deshmukh, O. S. (2017). Phytochemical and FTIR spectral analysis of Cycle peltata (Lamk.) hook an endemic medicinal plant. International Journal of Pharmaceutical Science and Research, 2(6):1215. 